\title{
Cluster Development in a Transforming Economy: The Case of Motorcycle Spare Parts Firms in Nnewi, Anambra State of Nigeria
}

\author{
Tobechi F. Agbanike ${ }^{1 \rtimes(D)}$ \\ Augustine C. Osigwe ${ }^{2}$ (D) \\ Denis N. Yuni ${ }^{3}$ (ID \\ Thank-God C. Onoja ${ }^{4}$ \\ Sunday A. Okwor ${ }^{5}$
}

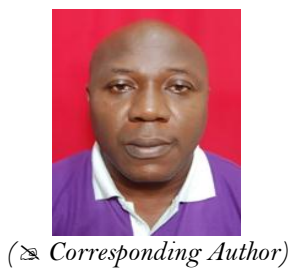

( Corresponding Author)

\footnotetext{
${ }_{1,3,5,5}$ Department of Economics and Development Studies, Alex Ekwueme Federal University, Ndufu-Alike, Ebonyi State, Nigeria.

'Email: tobechi_agbanike@yahoo.co.ukTel:+234-8063485467

sEmail:yuni.denis@unn.edu.ngTel:+234-7063985716

Email:musheshe@yahoo.co.ukTel:+234-8166630504

${ }^{5}$ Email:sundayamalu@gmail.com Tel: +234-8039559407

${ }^{2}$ Research and Training Division National Institute for Legislative Studies, National Assembly, Abuja, Nigeria.

'Email:acosigrwe@yahoo.com Tel: +234-8038728652
}

\section{Abstract}

This paper examined the impact of cluster development in Nnewi, Anambra State of Nigeria. The estimated parsimonious model revealed that capital and labour were significant determinants of sales made by the firms while the cluster dummy variable was insignificant. This insignificance of the cluster dummy variable implied that, in terms of total sales, there was no significant difference between firms in the cluster and firms outside the cluster. For the profit model, we found that capital, labour and the cluster dummy were significant at $1 \%$ level. Capital, labour and cluster dummy have a positive relationship with firm profit. The positive coefficient of the cluster dummy variable indicated that the profit of firms in the cluster was significantly higher than that of the firms outside the cluster by about $\$ 1$ 1,050. It was therefore concluded that cluster residency made a significant difference in firm profit and recommended that government should encourage cluster development to accelerate the transformation of the economy.

Citation | Tobechi F. Agbanike; Augustine C. Osigwe; Denis N. Yuni; Thank-God C. Onoja; Sunday A. Okwor (2019). Cluster Development in a Transforming Economy: The Case of Motorcycle Spare Parts Firms in Nnewi, Anambra State of Nigeria. Economy, 6(1): $13-24$.

History:

Received: 23 April 2019

Revised: 31 May 2019

Accepted: 3 July 2019

Published: 6 September 2019

Licensed: This work is licensed under a Creative Commons

Attribution 3.0 License $($ (c) $)$ E

Publisher: Asian Online Journal Publishing Group
Acknowledgement: All authors contributed to the conception and design of the study.

Funding: This study received no specific financial support.

Competing Interests: The authors declare that they have no conflict of interests.

Transparency: The authors confirm that the manuscript is an honest, accurate, and transparent account of the study was reported; that no vital features of the study have been omitted; and that any discrepancies from the study as planned have been explained.

Ethical: This study follows all ethical practices during writing.

\section{Contents}

1. Introduction

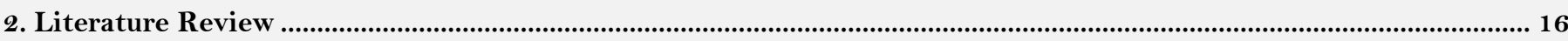

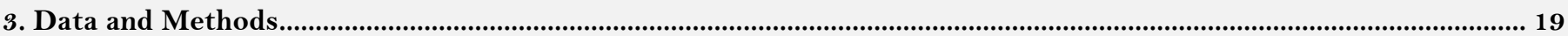

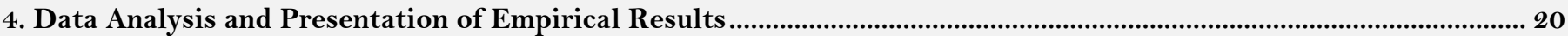

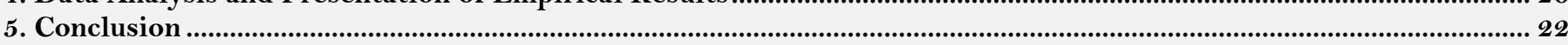

References 


\section{Contribution of this paper to the literature}

This study contributes to the existing literature by examining the impact of cluster development in Nnewi, Anambra State of Nigeria.

\section{Introduction}

\subsection{Background to the study}

In terms of official documentation, the concept of cluster is relatively new in Nigeria. Cluster initiatives began to gain prominence in the country in early 2007 when the Federal Government embraced the cluster model, recommended by the Federal Ministry of Commerce and Industry (FMCI) as a new Industrial Development Strategy for Nigeria. FMCI (2007) remarked that the concept of cluster was not completely a policy shift but a refocusing of implementation strategy to accelerate industrialization. According to Iwuagwu (2011) the strategy, therefore, proffered key steps, needed to position the country on the path to rapid industrialization and thus achieving its vision of becoming one of the twenty largest economies in the World by the year 2020.

FMCI (2007) documented that the concept of cluster would operate on five planks: Free Trade Zones; Industrial Parks; Industrial Clusters; Enterprise Zones ${ }^{1}$; and, Incubators ${ }^{2}$. Free Trade Zones was defined as fertile land for economic activities usually located in the proximity of seaports or international airports (both entry and exit points). In such zones, goods are brought in or taken out of the country without the usual payment of duties crosschecked. This is because the zones are considered to be aside customs' jurisdiction. Therefore the federal government would create more of such zones throughout the country to beef the existing ones, while the zones would grant special motivations to attract FDIs. Industrial parks were described as mega parks covering areas of between 30 - 50 square kilometres for large manufacturing enterprises with great value addition in the production of goods. According to FMCI (2007) it was planned that at least one park located in each of the six geo-political zones of the country. Each of these parks was to focus on processing products which the zone has comparative and competitive advantages over others.

Economic activities are clustered to create a controlled environment for industrialization to flourish, face especially in the presence of chronic infrastructural deficits. Nigeria does not only have a number of large industrial estates and complexes but also witnessed the spontaneous development of small clusters across the country. The latter includes Computer Village in Otigba, Lagos, the auto and industrial spare parts fabricators in Nnewi, the leather tannery in Kano and the footwear, leatherworks, and garment cluster in Aba. There are approximately 25 free trade zones licensed by the federal government (Chete et al., 2014).

Since independent in 1960, swift economic development through industrialization has remained a mirage in Nigeria. Ever since, diverse approaches to industrial development have been adopted by different administration. In addition, different economic development policies which have bearing on the industrial sector have also been adopted in the past five decades. Among these policies are: Import Substitution Strategy (ISS), Indigenization Policy and the Structural Adjustment Program (SAP). In the opinion of Iwuagwu (2011) the challenges of the industrial sector remained unresolved despite adoption of these policies. Nigeria strayed further away from industrialization in the wake of the policies.

Amakom (2006) earlier observed that despite successive governments' efforts to encourage industrialization, minimal positive results have been achieved and the industrial sector remains poorly developed. Available statistics from the Central Bank of Nigeria (CBN) (2015) indicates that the manufacturing sub-sector on the average accounted for $5.19 \%$ of Nigeria's RGDP between 1981 and 1985 . Between 1986 and 1990, it averaged $6.81 \%$ and later declined to $4.46 \%$ from 1991 to 1995 ; between 1996 and 2000, it nosedived to $3.60 \%$; and marginally increased to $3.65 \%$; from 2001 to 2005 . The manufacturing sub-sector contribution to the RGDP averaged at $4.08 \%$ between 2006 and 2010 and slightly increased to $4.20 \%$ from the year 2011 to 2014 Figure 1.

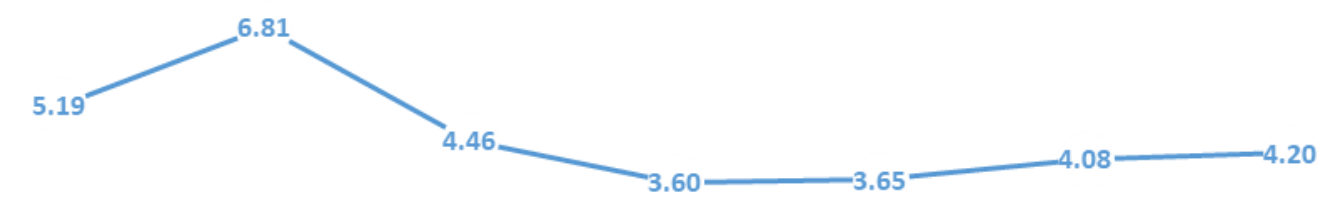

\begin{tabular}{cccccc}
\hline $1981-85$ & $\begin{array}{c}1986-90 \\
\text { Figure-1. Manufacturing sector contribution to real GDP (percentage). }\end{array}$ & 2011-14 \\
Source: Authors' analysis based on data from CBN (2015).
\end{tabular}

\subsubsection{Nigeria Industrial Revolution Plan}

The Nigeria Industrial Revolution Plan (NIRP) released in January, 2014, is a five-year plan to rapidly build up industrial capacity and improve Nigeria's competitiveness. It aimed at increasing the contribution of manufacturing to GDP from its 4 per cent value in 2013 , to 6 per cent by 2015 , and finally above10 per cent by 2017 . The NIPR is driven by the desire to a process of intense industrialization, based on sectors where Nigeria has comparative advantages, such as the agro-allied sectors; metals and solid minerals-related sectors; oil and gas related industries; as well as construction, light manufacturing and services. The NIRP also addresses the numerous issues that have

${ }^{1}$ A specific geographical area that has been designated by a governmental authority (usually federal). Businesses within the enterprise zone are entitled to receive various types of financial aid. These include tax benefits, special financing and other incentives designed to encourage businesses to establish and maintain a presence within the specified zone. Enterprise zones are often established in low-income areas or places that are recovering from disaster. Business

are encouraged, through cost savings, to open their doors and hire local residents within these areas in order to stimulate economic growth.
${ }^{2}$ Incubators create room for business development services covering key development areas, access to an extensive international network of key industry ${ }^{2}$ Incubators create room for business devel
players, as well as facilitate investor contacts. 
held back the Nigerian non-oil sector for years; it addresses the high cost of funding and lack of long-term finance in Nigeria; it builds up industrial infrastructure and power for industry; provides industrial skills; links innovation and industry; improves our investment climate; strengthens product standards; and promotes local patronage (Ministry of Industry Trade and Investment, 2014). The NIRP is expected to drive the following outcomes:

- Job creation.

- Economic and revenue diversification.

- Import substitution.

- Export diversification.

- Broadened government tax base.

\subsubsection{Brief Background Story of Nnewi}

Nnewi is a major industrial and commercial hub in Nigeria. High commercial undertakings in the town attract many merchants. Nnewi is home to the first car producing firm in Nigeria and 'NASENI M1' - the first locally produced motorcycle - was manufactured in the town.

In the context of manufacturing, Nnewi is loosely described as the Japan of Africa. This is because it hosts local firms, including Cutix and ADswitch, Cento Group of Companies, Coscharis Group of Companies, Ibeto Group of Companies, Omata Holdings Ltd, Uru Industries Ltd, Ejiamatu Group of Companies, Innoson Group of Companies, Louis Carter Group, John White Industries, Ebunso Nig. Ltd, Chikason Group, and so on. Most of these firms double as dealers who market some of their products (typically motor parts) through their distribution channels.

\subsection{Statement of the Problem}

Nigeria's low level of industrialization is linked to its colonization. Efforts of the colonial masters towards industrializing the country could at best be described as abysmal (AIAE, 2006). They focused mainly on excavating and exporting to Britain, raw materials that served as industrial inputs and importing to Nigeria finished goods that sold at exorbitant prices. In other words, they showed commitment to the execution of any effective industrialization policy. AIAE (2006) corroborates the foregoing as follows;

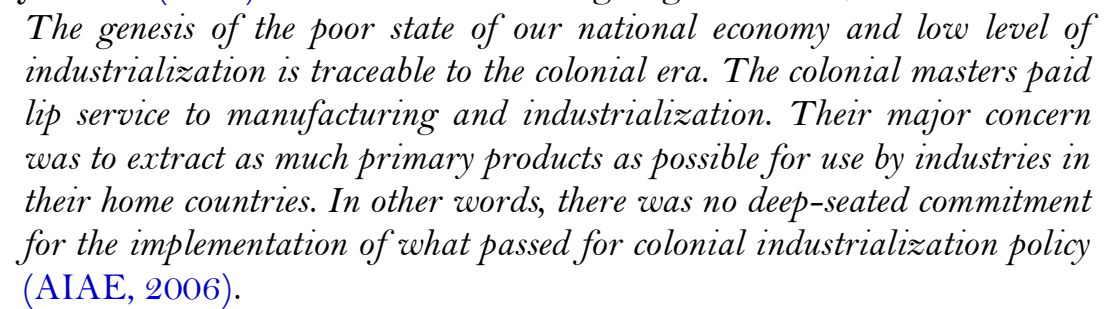

A number of significant barriers hamper the growth of the Nnewi cluster. These include: lack of necessary infrastructure, absence of skilled workforce, failure to systematically connect with stakeholders both inside and outside of their networks (including businesses and universities), conservatism in business enterprises, bribe and corrupt practices, volatile local business environment, poor policy implementation, inefficient public administration and policy inconsistency. Other challenges confronting cluster development in Nnewi include but not limited to: lack of access to credit, high interest rate, high tariff and declining sales (see, AIAE (2006)).

Furthermore, due to the massive revenue from crude oil, some regimes abandoned other crucial economic sectors, manufacturing inclusive. This negligence aggravated the state of the national economy. Instead of being proactive, different administrations focused mainly on crude oil revenue without any deliberate effort and commitment to ensuring the execution of spirited industrial policies for economic development. Thus, the belief that crude oil abundance is a curse rather than a blessing to Nigeria; a phenomenon popularly referred to as the Dutch disease.

The persistent insecurity of lives and property in the country occasioned by armed robbery, assassinations, kidnappings and, more recently, bombings in Northern parts of the country, constitute major hindrances to cluster development. Such anti-social and anti-growth activities do not encourage entrepreneurs to perform optimally; they rather discourage the inflow of FDI into the country. A case in point was the closure of some telecommunication industries' services in the northern part of the country due to insecurity in the area.

Based on the foregoing, the following research objectives shall guide this study:

\subsection{Research Objectives}

This study examines the impact of cluster development on a transforming economy with specific reference to motorcycle spare parts firms in Nnewi, Anambra State of Nigeria. To achieve this, the following specific objectives are pursued:

i) To identify the difference in performance between motorcycles spare parts firms in cluster and outside cluster in Nnewi, Anambra state.

ii) To assess the impacts of cluster residency on the performance of motorcycle spare parts firms in Nnewi, Anambra state.

iii) To examine the enabling conditions and barriers to the growth of motorcycle spare parts cluster in Nnewi, Anambra state.

iv) To determine the effects of government policies on the motorcycle spare parts cluster in Nnewi, Anambra state.

\subsection{Justification of the Study}

This study is motivated by the increasing consciousness on the significance of motorcycle spare parts business in the socioeconomic development of Nigeria. For instance, the business is capable of improving people's income and creating more employment opportunities. The outcome of this study will be of immense benefit to Nigerians as 
it will to focus on the contributions of motorcycle spare parts business and the informal sector in general to socioeconomic development of the people. Last year, the federal government of Nigeria advised state governments across the country and the Federal Capital Territory (FCT) to ban ${ }^{3}$ motorcycles as a means of commercial transportation. Prior to the advice, many states ${ }^{4}$ had implemented the 'OKADA' ban policy in some of their major cities. The policy, no doubt, will have ripple effects on motorcycle spare parts business, at least, starting with the fall in the demand for motorcycle and its spare parts by those who use it for transportation business. Against this backdrop, this study, among other objectives, examined the effects of government policies on the motorcycle spare parts cluster in Nnewi, Anambra state.

As identified in the literature, cluster of factories contribute to economic development, at least in the area of job creation (see, Sparks and Barnett (2010)). The alarming rate of unemployment in Nigeria with its agonizing effects has become a subject of concern to both the government and other stakeholders in the economy. According to the NBS (2012) with the current unemployment rate of 23.9 per cent and unemployed youth population of 20.3 million, Nigeria still generates about 4.5 million new entrants into the labour market annually. Even though the government has been making efforts to address this ugly trend, the status quo still remains. Expectedly, when firms perform well in terms of sale and profit, their capacity to employ more labour force and pay taxes increases. However, the ban on 'OKADA' discourages manufacturing and employment of labour. Given the unemployment situation in the country, we investigate, among other things, the difference in performance (sale and profit) between motorcycle spare parts firms in cluster and outside cluster in Nnewi, Anambra State. The findings of this study will provide evidence for policy purposes.

Previous studies have examined the effects of industrial clusters on the Nigerian economy (see for example, (Oyelaran-Oyeyinka, 2001; Uzor, 2004; Abiola, 2006; Amakom, 2006; Iwuagwu, 2011)). The specific objectives of these studies differ markedly on account of many factors, ranging from the typology of cluster of interest to location of cluster. Of all these studies, Amakom (2006) and Oyelaran-Oyeyinka (2001) are of particular interest to this research. Amakom (2006) attempted to find out if the same problems that bedeviled other industries that are scattered all over the country are also affecting those in the industrial clusters whereas Oyelaran-Oyeyinka (2001) investigated the basis for long-term sustainable development of industrial clusters in Lagos, Nigeria and compared the metropolitan clusters with the Nnewi cluster, located within a rural setting in a homogeneous ethnic community. None of these studies examined the impact of cluster residency on the performance of motorcycle spare parts firms in Nnewi. This makes the present study relevant and timely.

Finally, the review on the rationales for industrial cluster presented in section 2.2 indicates a plethora of reasons supporting cluster-focused economic development strategy. Among these reasons are: access to markets, technological spill overs, potentials to enable more entrepreneurs to participate in industrial production, lowering the capital barriers to entry, ensuring competitiveness of firms and fast-tracking industrial and economic growth, boosting innovation, entrepreneurship, wages, and business specialization. To know the extent to which the Nnewi motorcycle spare parts cluster delivers on a number of these, it is necessary to conduct a study of this nature.

\section{Literature Review \\ 2.1. Conceptual Issues}

Industrial cluster simply refers to the concentration of economic activities of a certain sector or group of firms that produce similar and closely related goods in a given location. According to Porter (2000) clusters 'represent a new way of thinking' about economic growth at all levels, but which requires new roles for companies, government agencies, universities and other organizations in enhancing competitiveness. In a study carried out for the World Bank on Ethiopia, Ali (2012) strongly argues that cluster development programmes have become increasingly widespread tools in fostering innovation and growth of a competitive private sector in developing countries. To Schmitz and Nadvi (1999) industrial clusters provide a wide range of advantages that enable enterprises to become competitive and profitable.

Martin and Sunley (2003) note that clustering has two dimensions. First, the functional dimension which includes local inter-firm linkages and forward and backward linkages with such interconnected agents as input suppliers and output buyers. Such linkages, they maintain, often result in social interrelationships that are expressed through trust and collaborative networks that develop over a long period of time. Second, the physical dimension that points to the physical co-location of enterprises close to one another (geographic proximity) in the cluster. They argued that while geographic proximity helps stimulate the functional dimensions of clustering, it does not offer a direct view about the nature and strength of local inter-firm linkages and social networks.

Ali (2012) use a diagram to depict an example of composition of an industrial cluster. In the diagram, he shows that industrial cluster involves the supply of both raw materials and machinery within a group of related firms. This group of firms could have common service providers in terms of designing, maintenance, finance, training and so on. It is also clear from the diagram that there are public and private institutions whose activities affect the operations of the firms. These activities could be in the areas of policies, research or even in the other forms of cooperations. Lastly, the firms could get their outputs across to the final consumer directly or through the help of selling agents Figure 2.

\footnotetext{
${ }^{s}$ Three main reasons adduced by the government for the ban policy are; high rate of crippling and fatal accidents per unit of distance travelled, increased rate of crime and Okada business has been criticized for causing or exacerbating traffic congestion in the cities where they operate

${ }^{4}$ These states include, Lagos, Imo, Niger, Rivers, Delta, Enugu, Edo, Kano, Plateau, Kaduna.
Then
} 


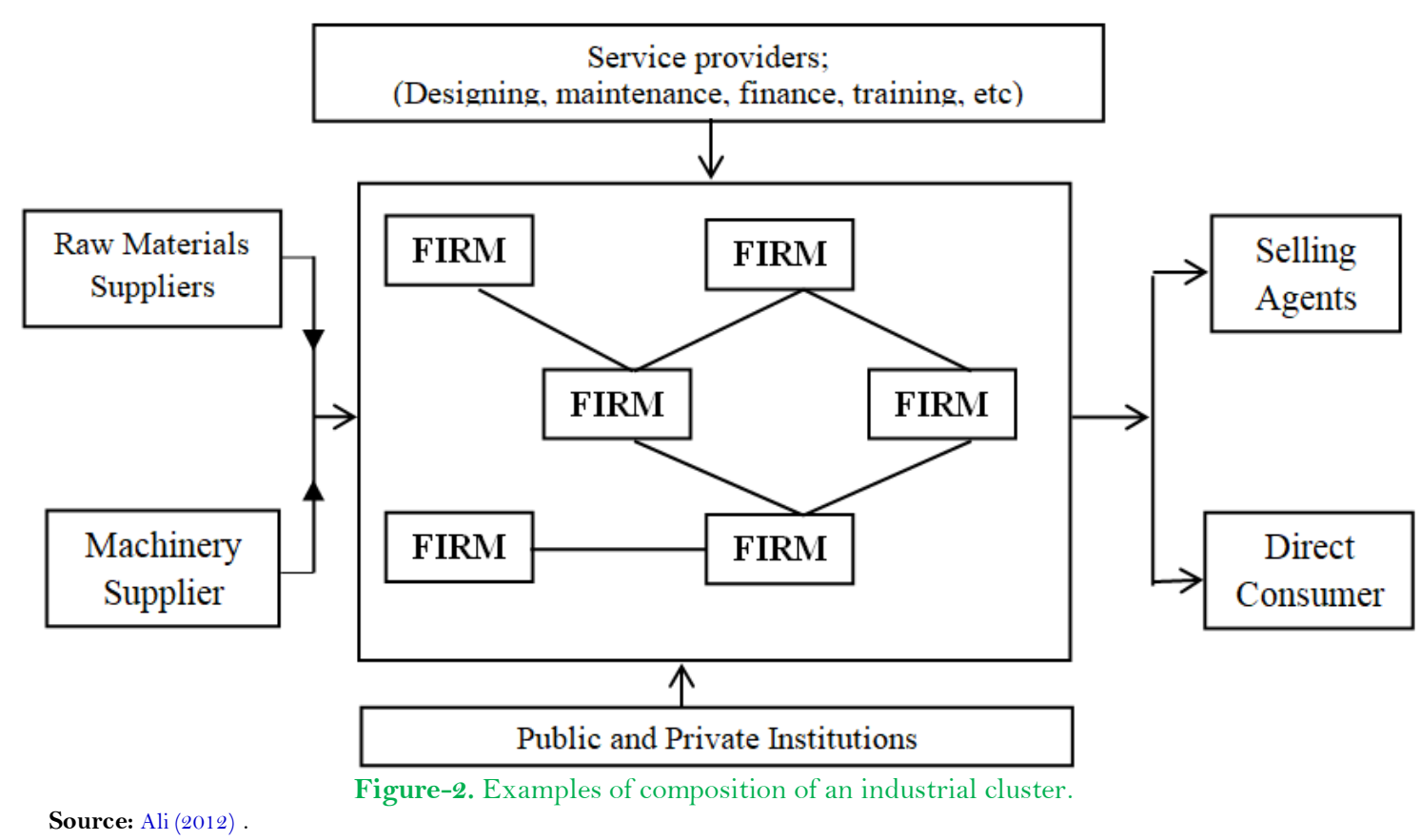

To Clar et al. (2008) different approaches have been developed towards facilitating clusters. They acknowledged that four main schools of thought have emerged in this regard Table 1. The Californian and Nordic schools of thought are tied to economic systems while the Industrial and Porter's industrial cluster are more generic. According to them, the $\mathrm{OECD}^{5}$ countries have engaged in a good deal of experimentation with respect to the various approaches. Table 1 situates the Nnewi motorcycle spare parts cluster within the hybrid of industrial and Porter's industrial cluster.

Table-1. Four schools of thought on clustering.

\begin{tabular}{l|l}
\hline School of thought & Characteristics \\
\hline Industrial district & $\begin{array}{l}\text { External economies, mutual trust and a positive atmosphere of cooperation } \\
\text { between companies, leading to incremental innovations. }\end{array}$ \\
\hline Californian school & $\begin{array}{l}\text { Vertical disintegration, reduced transaction costs and a specialized local labour } \\
\text { market, plus conventions, informal rules, and habits, leading to greater } \\
\text { collaboration among companies. }\end{array}$ \\
\hline Nordic school & $\begin{array}{l}\text { Innovation as the basis for obtaining competitiveness for firms, regions and } \\
\text { nations, learning is seen as mainly a localised process, information is relatively } \\
\text { globally mobile, knowledge is remarkably spatially rooted. }\end{array}$ \\
\hline Porter's industrial cluster & $\begin{array}{l}\text { External economies strengthened by proximity and better access to input factors, } \\
\text { local rivalry, and local customers; collective improvement of the competitiveness of } \\
\text { companies and creation of opportunities for the establishment of new niche } \\
\text { companies to support the expansion of local supply chains and add more value to } \\
\text { the cluster. }\end{array}$ \\
\hline
\end{tabular}

\subsection{Rationales for Industrial Cluster}

There seems to be a consensus ${ }^{6}$ on the relevance of clustering as an alternative strategy for industrial development in developing countries. For example, Adam Smith chronicled the economic gains available to firms through the division of labour, an indisputable characteristic of industrial clustering. Following this, Marshall (1920) recognised that industrial clusters enjoy at least three well-known major benefits, namely, access to markets, labour market pooling, and technological spill overs (Krugman, 1991). Extending Marshall's view, Schmitz (1995) and Schmitz and Nadvi (1999) observe that embedded in these benefits are the potentials to enable more entrepreneurs to participate in industrial production that may otherwise be inaccessible to them. These benefits have been branded 'collective efficiencies' in the literature. Ruan and Zhang (2009) identified a further important collective efficiency of clustering mechanism. To them, clustering can assist in lowering the capital barriers to entry through division of the production processes among firms, thus enabling more firms with otherwise limited capital to enter the production process/chain. Cluster development is usually considered as one of the ways of ensuring competitiveness of firms and fast-tracking industrial and economic growth (see for example, (Mwamila and Diyamett, 2011; Brakman and Van Marrewijk, 2013)).

More so, clustering is believed to offer unique opportunities to engage in the wide array of domestic linkages between users and producers, between the knowledge-producing sector.

(Universities and R\&D Institutes) and the goods and services-producing sectors of an economy that stimulates learning and innovation (Nadvi, 1995; Nadvi and Schmitz, 1997; Meyer-Stamer, 1998a).

Clusters drive productivity and innovation. Firms that are located within a cluster can transact more efficiently, share technologies and knowledge more readily, operate more flexibly, start new businesses more easily, and perceive and implement innovations more rapidly. They can also efficiently access "public goods" such as pools of specialized skilled employees, specialized infrastructure, technological knowledge, and others. Clusters embody traditional notions such as input-output linkages, among others. Because of the importance of physical proximity in reaping cluster benefits, clusters are often regional instead of national except in small countries (Porter, 2009).

${ }^{5}$ OECD means Organisation for Economic Cooperation and Development and is usually considered as the club of the rich countries.

${ }^{6}$ See the studies by Meyer-Stamer (1998b); Weijland (1999); Bell and Albu (1999); Porter (2000); Gordon and McCann (2000); Fujita et al. (2001); Sonobe and Otsuka (2011); Nakabayashi (2006) and Ruan and Zhang (2009). 
Clusters and cluster strategies have the potential to accelerate regional economic growth and assist in economic restructuring. At a time of tepid growth, cluster strategies possess documented power to help power regional economic growth by boosting innovation, entrepreneurship, wages, employment and business specialization. At a time of shaken confidence in past growth models, cluster frameworks point to the centrality to national wellbeing of practical economic systems in regions and so offer a fresh paradigm for new thoughts on national economic management. And finally, as a policy framework, clusters provide a practical tool for policy coordination and possibly increased return on public investments. Clusters deliver significant productivity advantages to groups of firms, suppliers and related actors and institutions that draw mutual advantage from localization (Muro and Bruce, 2010).

In the Nigerian context, Iwuagwu (2011) argues that clustering would permit greater focusing of public resources as infrastructural facilities would be concentrated in identified locations, especially for industrial and commercial purposes. According to him, because of geographic proximity of firms as well as financial and other business institutions, clustering would enhance the effectiveness of the innovation process required to kick start Nigeria's industrial take-off. It would also encourage localization of economies and enhance the likelihood of interfirm technology and information transfers as well as motivate companies in Nigeria to go into product specialization and adoption of new technologies.

\subsection{Cluster Development and Economic Growth}

Empirical literature on the role and importance of clusters in supporting economic development is mixed and still emerging. There is a huge body of empirical literature supporting clustering as the key determinant of economic development (see for example, (Audretsch and Feldman, 1996; European Commission, 2002; Lee et al., 2017; Zeibote, 2018)). Several international bodies have been advocating for cluster development. They include the OECD, the World Bank, the Inter-American Development Bank (IADB), the United Nations Conference on Trade and Development, the World Economic Forum, and the United Nations Industrial Development Organization. As noted by Choe and Roberts (2011) advocacy has helped to move the debate from the academic sphere to the realm of policy and business.

According to UNIDO (2010) cluster concept has gained prominence as an economic policy tool aimed at fostering innovation and growth of a competitive private sector in developing countries. UNIDO (2010) maintains that, recently, donors and development agencies have paid increasing attention to the potential of cluster initiatives to bring about pro-poor effects. The organization is of the view that thriving clusters can generate employment, income and opportunities for the local community and become drivers of broad-based local economic development. UNIDO (2010) further state that in the framework of private-sector development initiatives, cluster-based interventions have gained momentum. According to the organization, three main arguments can be advanced to explain the focus on clusters as targets of development assistance: i) Collective efficiency gains; ii) Spatial proximity effects; and iii) Pro-poor potential.

Using Arizona as a case study, Waits (2000) presented a practical evidence of the benefits from cluster-based economic development strategy. He asserted that clusters of world-class firms in related industries are the most important economic development clusters in the global economy. According to him, these clusters, rather than individual companies or simple industries, are source of jobs, income and export growth. This is what Arizona has found to be the case. He maintains that, as a result of cluster-focused economic analysis and strategy development, Arizona has a better understanding of its economy and economic development clusters. The state also has a viable approach - cluster working groups and organizations - for putting industries together to design policies, address common problems and implement initiatives.

Oyelaran-Oyeyinka (2001) investigates the basis for long-term sustainable development of industrial clusters in Lagos, Nigeria, comparing the metropolitan clusters with the Nnewi cluster, located in a rural homogeneous ethnic community. According to him, the characteristics of clustering examined are: the forms and intensity of inter-firm linkages, including the formation of trade networks and the role of business associations. He found a significant level of collaboration among firms in sharing utilities and modest forms of subcontracting non-core activities among Lagos firms, but this is not prevalent in Nnewi. He further reveal that the Lagos clusters have relatively high proportions of educated manpower. However, this important asset is underemployed in a situation of low growth rate of demand for quality products. In addition, the study shows that the firms in Nnewi, on the other hand, are owned by semi-illiterates who came from trading backgrounds into manufacturing. Networks such as industry associations were found to be playing vital roles such as information providers and as links to the global market even though the benefits are still latent. Ethnic and kinship ties were identified to play a prominent role at Nnewi while social networks and non-family ties were found to be more important in the Lagos clusters. The study suggested that non-economic factors exert profound influence on the evolving forms of industrial organisations in late industrialisation.

Uzor (2004) examined the cluster concept and its impact on private sector development in Africa in general and on SME development in Nigeria in particular. The findings of the study indicate that there are no effective institutions supporting cluster development in Africa in general and in Nigeria in particular. Competition and learning were considered in the study as two important elements needed in African clusters given that they are the benchmark for the private sector development in the region. Limitations of the clusters in the region were classified into; i) level of education of the entrepreneurs, ii) weak government, institutional support and market development, and iii) financial constraints of the SMEs needed for expansion. The study recommended the need for partnership building among the state, institutions and the private sectors for SME development. Such relationship plays an important role in economic development generally, especially in infrastructure and in capacity building. More so, the study added that policy objective for the support of technical education and training is imperative in the South East region and in Nigeria generally.

Amakom (2006) attempted to find out if the same problems facing other industries scattered all over the country are also affecting those in the industrial clusters which the government claims to be more environment friendly. The study employed data from the UNIDO survey 2006 on leather industry in Kano industrial cluster. 
Also the study employed Probit regression and found that the inability of the leather sector to meet its target is due to low efficiency caused by poor technical know-how cum high cost of doing business (high indirect costs as a result of inadequate of physical infrastructure) which resulted to low capacity utilization. According to Amakom, this finding is not at variance with the findings of studies involving other firms scattered all over the country. Therefore it would be erroneous to accept any hypothesis that firms within the industrial cluster have friendlier environment.

A study by Abiola (2006) focused on three key elements: the origin of investment in manufacturing technology; the technological learning strategy and mechanism; and the technological capabilities acquired. The study which was titled Knowledge, Technology and Growth: The Case Study of Nnewi Auto Parts Cluster in Nigeria discovered that majority of firms implemented technical change simply to improve old processes. It was revealed in the study that foreign technological linkages currently form the basis of development. Abiola identified the major obstacles to getting or procuring the foreign inputs for production of machinery and automotive components in Nnewi cluster as follows: tariff and non-tariff, finance, custom formalities, information and security of lives.

\subsection{Industrial Clusters in Different Countries and Industrial Regions of the World}

In Latin America, the Brazilian Shoe Cluster of Sinos Valley is remarkable. Brazil is one of the world's leading producers of leather shoes and the bulk of its export-oriented leather shoes are produced in the Sinos Valley industrial cluster. Three factors have been noted for Sinos Valleys' economic success. They are: i) backward linkages with local input suppliers; ii) forward linkages with producers and buyers, mainly export agents; and iii) the tactical intervention of local support institutions in aiding the cluster's capacity to move into higher value added product markets.

Clusters in East Asia have been successful as a result of the following; i) imitation and assimilation of foreign technologies, ii) the formation of geographically dense industrial clusters consisting of a large number of small enterprises producing similar and related products and, iii) the advent of manifold innovations leading to progress in the industrial structures. For instance, China and Taiwan modelled their industrial development after that of Japan.

Pakistan's industrial cluster located in Siatkot produces surgical equipment and is export-oriented. Siatkot Surgical Instrument Industrial Cluster's success is enormous as a result of the producers' ability to meet high export standards. Also, it adopted in no small measure designs and technical experts from Britain besides the development of technical institutions for the training of workers.

\section{Data and Methods}

The study adopted the survey method to evaluate the impacts of cluster of motorcycle spare parts factories in Nnewi on the economy of Anambra state. The population of the study includes all motorcycle spare parts factories operating in Nnewi; Anambra State. Some of these firms are clustered within 21 unequal zones (clustered firms) while others are outside the cluster (non-clustered firms). The purposive sampling technique was adopted in the selection of three zones - zone 6 (300 dealers), zone 13 (200 dealers) and zone 10 (100 dealers). The selected zones have characteristics that typically represent the firms in the cluster. For instance, the largest number of dealers is found in zone six and it is considered as the hot spot of the cluster. Zone 10 possesses the direct opposite of the characteristics of zone 6 whereas zone 13 represents the moderate of zones 6 and 10. The Yaro Yamane's formula (Yamane, 1967), $n=\frac{N}{\left(1+N[e]^{2}\right)},(\mathrm{n}=$ sample size, $\mathrm{N}=$ population and e = error margin) was employed to develop a representative sample size of 384 motorcycle spare parts from the population of the three zones. In addition, 384 non-clustered motorcycle spare parts factories were randomly ${ }^{7}$ sampled to serve as a control. In all, 768 motorcycle spare parts factories were surveyed. The validity and reliability of the instruments were tested to ensure efficiency.

The study employed the t-test distribution technique, multiple regressions and descriptive analysis to achieve its objectives. To achieve the first objective of identifying the difference in performance of firms in cluster and the non-clustered firms, the t-test of significance was employed. The specific performance indicators examined are; volume of sales, capital, labour and profit.

For the second objective of assessing the impact of cluster residency on the performance of motorcycle spare parts firms in Nnewi, Anambra state, three multiple regression models (with profit and sales as dependent variables) were estimated. The compact version of the estimated econometric equation is presented as:

$$
Y_{i}=\beta_{0}+\sum_{i=1}^{n} \beta_{i} X_{i}+\varepsilon_{\mathrm{\imath}}
$$

Where $Y_{i}$ is the dependent variable (sales or profit), $\beta_{0}$ is the constant term or the intercept, $\beta_{i}$ represents the coefficient of the determinants and $X_{i}$ the explanatory variables which include: cluster dummy ( 1 if firm is in a cluster and o otherwise), capital, labour, experience of firm head, years of education of firm head, age of firm head and access to credit dummy ( 1 if firm has access to credit and 0 otherwise). $n$ represents the number of explanatory variables while $\varepsilon_{1}$ stands for the error or residual term.

The third and fourth objectives which were to examine the enabling conditions and barriers to the growth of motorcycle spare parts cluster and to determine the effects of government policies on the motorcycle spare parts cluster in Nnewi, Anambra state were achieved by employing the likhert scale. The likhert scale was used in ranking the responses whereas the means were derived to show the average position of the respondents. 


\section{Data Analysis and Presentation of Empirical Results}

Data collected first underwent manual editing. This was followed by the coding of the completed questionnaire, data entering, processing and analysis, using the appropriate statistical packages. The results of the analysis are presented in Appendix 1 and discussed in the next section.

\subsection{Differences in Performance of Firms in Cluster and Non-Cluster in Nnewi, Anambra State}

In terms of sales, the mean value of small firms in the cluster stood at N125, 112 whereas that of non-clustered small firms amounted to N121, 084.2. This difference was not statistically significant, judging from the absolute $t$ value of 0.34 . The mean value of sales of medium firms in the cluster was N319, 877 as against that of firms outside the cluster which was $\mathrm{N} 316,577.1$. The absolute $\mathrm{t}$ value of 1.98 indicate that the difference in sales of the two categories being compared was statistically significant. Similarly, the mean value of sale of the large firms was N4, 444,094 while that of the non-clustered firms came up to N4, 422, 870. This difference in mean sales value of large firms in cluster and outside cluster is statistically significant.

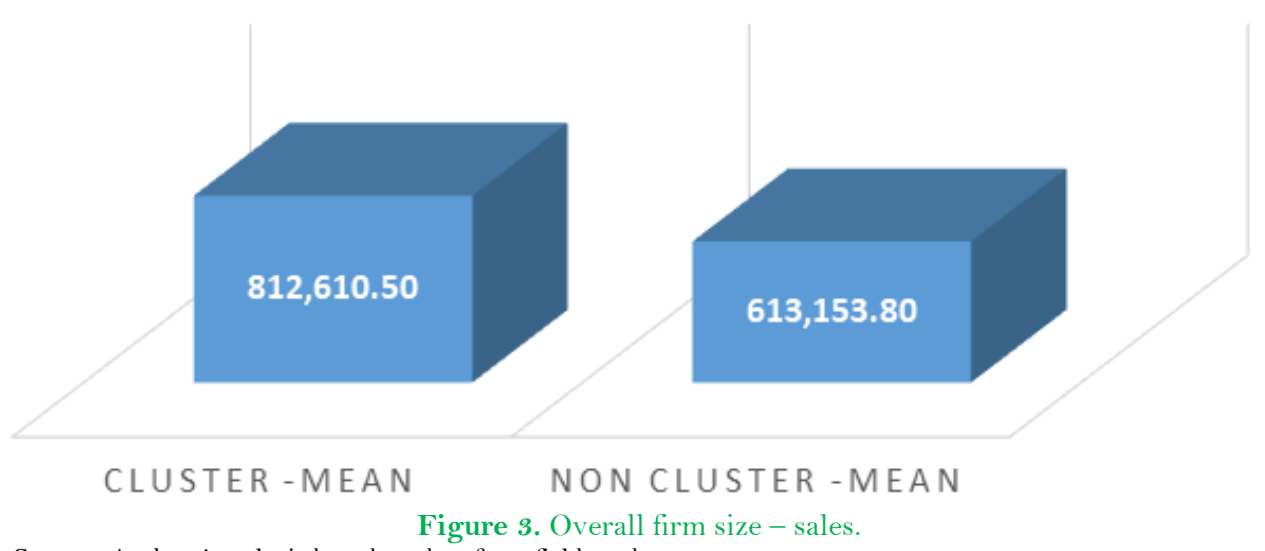

Source: Authors' analysis based on data from field study.

For the capital of the different firm sizes, no significant difference was found between firms within and outside cluster.

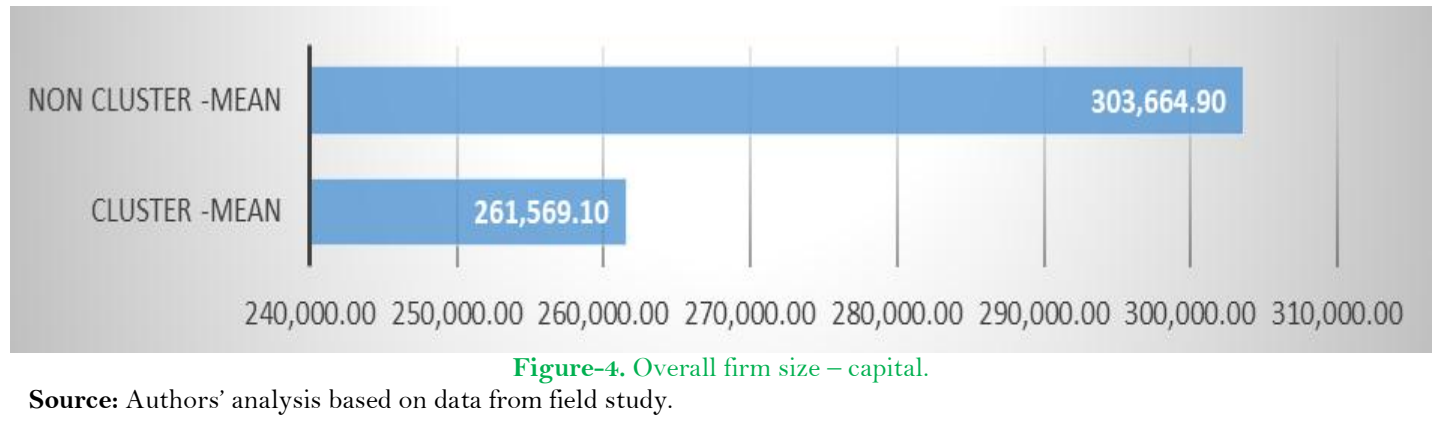

Similarly, no significant difference was found in the labour of clustered small and large firms and non-clustered small and large firms. However, a significant difference exists in clustered medium firms and non-clustered medium firms.

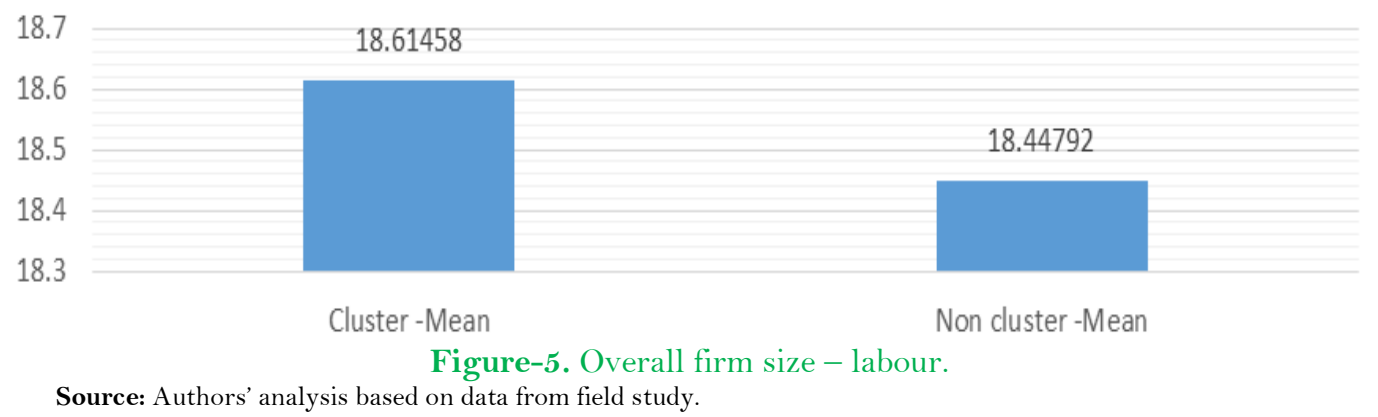

The mean profit of the three categories of firms in the cluster was significantly different from the mean profit of those outside the cluster.

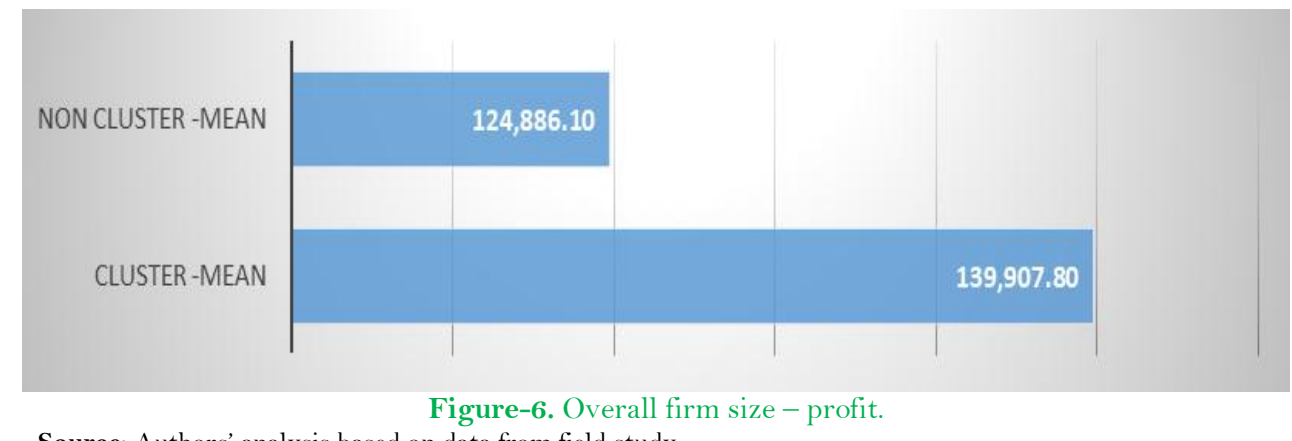

Source: Authors' analysis based on data from field study. 


\subsection{Impacts of Cluster Residency on the Performance of Motorcycle Spare Parts Firms in Nnewi, Anambra State}

The study estimated multiple regression models to show the impacts of cluster residency on output and profit of the firms. A dummy variable that connotes 1 if firm is in cluster and o otherwise was considered as the key variable. Other control variables were also considered. They include: capital, labour, experience of firm head, years of education of firm head, age of firm head and access to credit dummy. In all, three models consisting of two equations each were estimated. The first model is the complete model while the second and third represent its parsimony. The regression results of the three models are presented in Appendix 2.

The results show that the probability of the F-statistics of the models is less than 0.05 implying that the overall model is significant in each case. The $\mathrm{R}$ square values (ranging from $39 \%$ to $62 \%$ ) indicated that the models are reasonably of good fit considering the cross-sectional nature of the data. The mean variance inflation factor for all the models emerged quite low while all the individual variables showed negligible presence of multi-colinearity. The problem of heteroscedasticity was automatically addressed within the software.

In specific, the results from model 1 show that capital, experience of the firm head and access to credit are significant determinants of the sales of the firms. The said variables are positively related to sales, implying that increase in capital base of the firm and experience of the firm head leads to increase in sales. The results further reveal that firms that have access to credit have a significant difference in sales of about $\$ 50,493$ over firms that do not access credit. Interestingly, when the two least significant variables (age and years of education of firm head) were dropped in the second model, capital, experience of the firm head and access to credit remained significant determinants of sales of the firm. In the third model, where capital, labour and the cluster dummy were retained, capital and labour emerged significant while the cluster dummy remained insignificant. The cluster dummy variable which is the variable of interest was not significant in the three models. This showed that in terms of total sales, there is no significant difference between firms in the cluster and the non-clustered firms.

For the profit regressions, the results showed that only capital, labour and the cluster dummy were significant at $1 \%$ significant level. Experience of firm head was significant at $10 \%$ significant level while years of education of firm head, age of firm head and access to credit were not significant at all. Again, capital, labour and cluster dummy have a positive relationship with firm profit. The positive coefficient of the cluster dummy variable indicated that the profit of firms in the cluster is significantly higher than the non-clustered firms by about $\$ 33,351$. In addition to capital, labour and the cluster dummy, experience of the firm head became significant in the second model. Noteworthy is the fact that the cluster dummy variable was significant in all profit equations in the three models, unlike in the case of the sales equations. This therefore implies that though residing in clusters might not make a significant difference in total sales, it definitely makes a significant difference in profit. This could be explained by the fact that firms in clusters enjoy economies of scale and sometimes scope that reduce their overall cost of doing business, hence improving profits.

\subsection{Enabling Conditions and Barriers to the Growth of Motorcycle Spare Parts Cluster in Nnewi}

On the average, the respondents were indifferent to government's devotion to the cluster but disagreed that the government frequently attends to the needs of the cluster residents. They disagreed that the current location of the cluster in terms of distance to the market is beneficial. The respondents agreed that the road network of the cluster contributes positively to firm output. They also strongly agreed that the cluster encouraged localization of firms. They were indifferent as to whether taxation is lower for those in the cluster and disagreed that shops are unaffordable Table 2

\begin{tabular}{|c|c|c|}
\hline Description & Likert scale & Conclusion \\
\hline The government is very devoted to the cluster. & 4 & Indifferent \\
\hline The government frequently attends to the needs of the cluster residents. & 2 & Disagree \\
\hline $\begin{array}{l}\text { The current location of the cluster is beneficial in terms of sourcing raw } \\
\text { materials. }\end{array}$ & 4 & Agree \\
\hline The current location of the cluster is beneficial in terms of distance to the market. & 2 & Disagree \\
\hline The road network of the cluster contributes positively to firm output. & 4 & Agree \\
\hline The cluster has encouraged localization of firms and industries. & 5 & Strongly agree \\
\hline Taxation is lower for those in the cluster. & 3 & Indifferent \\
\hline Shops are unaffordable. & 2 & Disagree \\
\hline Business is easier now in the cluster. & 4 & Agree \\
\hline Shops are available. & 4 & Agree \\
\hline Clusters are the best option for development of small firms. & 5 & Strongly agree \\
\hline Health care services are available within the cluster. & 4 & Agree \\
\hline There is adequate electricity supply. & 2 & Disagree \\
\hline There is access to credit and other banking services. & 4 & Agree \\
\hline Security in the cluster is adequate. & 4 & Agree \\
\hline
\end{tabular}

Source: Authors' analysis based on data from field study.

On the average, they agreed on the following: the current location of the Cluster is beneficial in terms of sourcing raw materials; business is easier in the cluster; shops are available; healthcare services are available within the cluster; there is access to credit and other banking services; and security in the cluster is adequate. Further, they strongly agreed that clusters are the best options for the development of small firms and disagreed that there is adequate electricity supply in the cluster.

\subsection{Impact of Government Policies on the Motorcycle Spare Parts Cluster in Nnewi}

Our field study indicated that 'OKADA' ban policy has negatively affected motorcycle spare parts cluster in Nnewi, Anambra state. The average likert scale showed that the respondents strongly agree on this negative effect. The respondents agreed on three key issues as follows; "infrastructure is well developed in the cluster", "the 
initiatives of the government are meant at improving factory performance", and "government supports in addressing the challenges of the residents in the cluster". However, they disagreed that the government has done everything within its ability to optimise the functions of the cluster Table 3.

Table-3. Government policies on the motorcycle spare parts cluster in Nnewi.

\begin{tabular}{|c|c|c|}
\hline Description & Likert scale & Conclusion \\
\hline The 'OKADA' ban policy has negatively affected motorcycle spare parts cluster. & 5 & Strongly agree \\
\hline Infrastructure is well developed in the cluster. & 4 & Agree \\
\hline The initiatives of the government are meant at improving factory performance. & 4 & Agree \\
\hline Government supports in addressing the challenges of the residents in the cluster. & 4 & Agree \\
\hline The government has done all in its power to optimise the functions of the cluster. & 2 & Disagree \\
\hline
\end{tabular}

\section{Conclusion}

This paper examined the impact of cluster development on a transforming economy using motorcycle spare parts firms in Nnewi, Anambra State of Nigeria as a case study. In terms of sales, the mean value of medium firms, and large firms in the cluster stood at 319, 877 Naira and 4, 444, 094 Naira, respectively, whereas that of the nonclustered medium, and large firms were in turns, 316, 577.1 Naira and 4, 422, 870 Naira. The differences in mean value of sales of medium and large firms were found to be statistically significant, judging from their absolute tvalues of 1.98 and 2.09, respectively. The difference between the mean values of sales of small firms in the cluster and non-clustered small firms was statistically insignificant with an absolute t-value of o.34. For the capital of the different firm sizes, no significant difference was found between firms within and outside the cluster. Similarly, no significant difference was found in the labour of clustered small and large firms and non-clustered small and large firms. However, a significant difference ( $t$-value of 1.91) existed in labour of clustered medium firms and nonclustered medium firms. The mean profit of the three categories of firms in the cluster (small - 25,789.54 Naira, medium - 159,104.4 Naira and large - 390,383 Naira) was significantly different from those outside the cluster (small - 25,438.79 Naira, medium - 142,901.9 and large - 375,498.6 Naira).

In this study, three models consisting of two equations each were estimated. The first model was the complete model while the second and third represented its parsimony. The results from model 1 showed that capital, experience of the firm head and access to credit were significant determinants of the sales of the firms. The results further revealed that firms that access credit have significant difference in sales of about 50,493 over firms that do not access credit. In the absence of the two least significant variables (age and years of education of firm head) capital, experience of the firm head and access to credit remained significant. In the third model, capital and labour were still significant while the cluster dummy variable remained insignificant. The cluster dummy variable which is the variable of interest was not significant in the three models, implying that in terms of total sales, there is no significant difference between firms in the cluster and the non-clustered firms.

For the profit regressions, it was discovered that capital, labour and the cluster dummy were significant at $1 \%$ level while experience of firm head was significant at 10\%. However, years of education of firm head, age of firm head and access to credit dummy variable were not significant at all levels. Capital, labour and cluster dummy had a positive relationship with firm profit. The positive coefficient of the cluster dummy variable indicated that the profit of firms in the cluster was significantly higher than the non-clustered firms by about $\$ 33,351$. In the second profit model, in addition to capital, labour and the cluster dummy, experience of the firm head became significant at $5 \%$ level. Noteworthy is the fact that the cluster dummy variable was significant in all profit equations across the three models unlike in the case of the sales equations, thereby, implying that cluster residency makes a significant difference in firm profit. This could be explained by the fact that firms in clusters enjoy economies of scale and sometimes scope that reduce their overall cost of doing business, hence improving profits.

On the enabling conditions and barriers to the growth of motorcycle spare parts cluster in Nnewi, it was discovered that the respondents on the average were indifferent regarding the government's devotion to the cluster but disagreed that the government frequently attends to the needs of the cluster residents. They disagreed that the current location of the cluster in terms of distance to the market is beneficial. However, the respondents agreed that the road network of the cluster contributes positively to firm performance and strongly agreed that the cluster has encouraged localization of firms and industries in Nnewi. Finally, they were indifferent as to whether taxation is lower for those in the cluster and disagreed that shops were unaffordable.

\section{References}

Abiola, B., 2006. Knowledge, technology and growth: The case study of Nnewi auto parts cluster in Nigeria, knowledge for development (K4D) program. World Bank Institute, World Bank, Washington, D.C.

AIAE, 2006. Unleashing industrial clusters for growth and prosperity in South Eastern Nigeria. African Institute for Applied Economics, Proceedings from the Enugu Forum Seminar.

Ali, M., 2012. Government's role in cluster development for MSEs: Lessons from Ethiopia. Chr. Michelsen Institute (CMI) Repor ts, R 2012: 2. pp: $1-18$.

Amakom, U., 2006. Export constraints of the Kano Leather industry: A study of industrial clusters in Nigeria. Department of Economics, Nnamdi Azikiwe University, Awka, Nigeria.

Audretsch, D.B. and M.P. Feldman, 1996. R\&D spillovers and the geography of innovation and production. The American Economic Review, 86(3): 630-640.

Bell, M. and M. Albu, 1999. Knowledge systems and technological dynamism in industrial clusters in developing countries. World Development, 27(9): 1715-1734.Available at: https://doi.org/10.1016/s0305-750x(99)00073-x.

Brakman, S. and C. Van Marrewijk, 2013. Reflections on cluster policies. Cambridge Journal of Regions, Economy and Society, 6(2): $217-231$.

CBN, 2015. Statistical bulletin. Abuja, Nigeria: Central Bank of Nigeria.

Central Bank of Nigeria (CBN), 2015. Statistical bulletin. Abuja, Nigeria: Central Bank of Nigeria.

Chete, L.N., J.O. Adeoti, F.M. Adeyinka and O. Ogundele, 2014. Industrial development and growth in Nigeria: Lessons and challenges, WIDER Working Paper, No. 2014/019, The United Nations University World Institute for Development Economics Research (UNU-WIDER), Helsinki.

Choe, K. and B. Roberts, 2011. Competitive cities in the 21 st century: Cluster-based local economic development. Urban development series. Asian Development Bank, Mandaluyong City, Philippines. 
Clar, G., B. Sautter and S. Hafner-Zimmermann, 2008. Strategic cluster development: Applying strategic policy intelligence to create a joint research Agenda. Steinbeis-Europa-Zentrum, Stuttgart, Germany.

EC, 2002. Regional clusters in Europe. In observatory of European SMEs: edited by Arne Isaksen and Elisabet Hauge. Brussels: European Commission, Luxembourg.

European Commission, 2002. Regional clusters in Europe. In observatory of European SMEs: Edited by Arne Isaksen and Elisabet Hauge. Brussels: European Commission, Luxembourg.

FMCI, 2007. Nigeria's industrial development strategy (2007 - 2011): The Cluster Concept. Federal Ministry of Commerce and Industry, Abuja, Nigeria.

Fujita, M., P. Krugman and A.J. Venables, 2001. The spatial economy: Cities, regions, and international trade. Cambridge, MA: MIT Press.

Gordon, I.R. and P. McCann, 2000. Industrial clusters: Complexes, agglomeration and/or social networks? Urban Studies, 37(3): 513532.Available at: https://doi.org/10.1080/0042098002096.

Iwuagwu, O., 2011. The cluster concept: Will Nigeria’s new industrial development strategy jumpstart the country's industrial takeoff. Afro Asian Journal of Social Sciences, 2(2-4): 1-24.

Krugman, P., 1991. Geography and trade. Cambridge, Mass, USA: MIT Press.

Lee, S.J., G.T.R. Lin and P.H. Hsi, 2017. Industrial cluster development and its contribution to economic growth in Taiwan - Hsinchu Science and Industrial Park. The Journal of Scientific and Industrial Research, 76(5): $273-278$.

Marshall, A., 1920. Principles of economics. London: Macmillan.

Martin, R. and P. Sunley, 2003. Deconstructing clusters: Chaotic concept or policy panacea? Journal of Economic Geography, 3(1): 535.Available at: https://doi.org/10.1093/jeg/3.1.5.

Meyer-Stamer, J., 1998a. Clustering, systemic competitiveness and commodity chaines: How firms, business associations and government in Santa Catarina (Brazil) Respond to Globalization. International Workshop on Global Production and Local Jobs: New Perspectives on Enterprises, Networks, Employment and Local Development Policy. ILO, Geneva.

Meyer-Stamer, J., 1998b. Path dependence in regional development: Persistence and change in three industrial clusters in Santa Catarina, Brazil. World Development, 26(8): 1495-1511.Available at: https://doi.org/10.1016/s0305-750x(98)00072-2.

Ministry of Industry Trade and Investment, 2014. Nigeria industrial revolution plan. Abuja, Nigeria: NIRP Release 1.

Muro, M. and K. Bruce, 2010. The new cluster moment': How regional innovation clusters can foster the next economy. Washington: Metropolitan Policy Program, Brookings Institution.

Mwamila, B. and B. Diyamett, 2011. Tanzania: The evolving role of universities in economic development.” In Universities in Transition: The Changing Role and Challenges for Academic Institutions edited by Goransson Bo and Brundenius Claes. New York: Springer, Ottawa, Canada.

Nadvi, K., 1995. Industrial clusters and networks: Case studies of SME growth and innovation. Paper Commissioned by the Small and Medium Industries Branch, UNIDO.

Nadvi, K. and H. Schmitz, 1997. SME responses to global challenges: Case studies of private and public initiatives. Vienna, Austria: Wien Publisher.

Nakabayashi, M., 2006. Flexibility and diversity: The putting-out system in the silk fabric industry of Kiryu, Japan. Discussion Paper in Economics and Business, Osaka University, Osaka, Japan.

NBS, 2012. Annual abstract of statistics. National Bureau of Statistics, Abuja, Nigeria.

Oyelaran-Oyeyinka, B., 2001 . Networks and linkages in African manufacturing cluster: A Nigerian case study. Discussion Paper Series. The United Nations University, Institute for new Technologies, The Netherlands.

Porter, M., 2009. Clusters and economic policy: Aligning public policy with the new economics of competition. ISC White Paper. Harvard Business School, Boston, USA. Available

from https://pdfs.semanticscholar.org/eb8c/36b4af03600c0177be24c345cd3a2713efcd.pdf $\lceil$ Accessed October 6, 2014].

Porter, M.E., 2000. Location, competition, and economic development: Local clusters in a global economy. Economic Development Quarterly, 14(1): 15-34.Available at: https://doi.org/10.1177/089124240001400105.

Ruan, J. and X. Zhang, 2009. Finance and cluster-based industrial development in China. Economic Development and Cultural Change, 58(1): 143-164.Available at: https://doi.org/10.1086/605208.

Schmitz, H., 1995. Collective efficiency: Growth path for small-scale industry. The Journal of Development Studies, 31(4): 529-566.Available at: https://doi.org/10.1080/00220389508422377.

Schmitz, H. and K. Nadvi, 1999. Clustering and industrialization: Introduction. World Development, 27(9): 1503-1514.Available at: https://doi.org/10.1016/s0305-750x(99)00072-8.

Sonobe, T. and K. Otsuka, 2011. . Cluster-based industrial development: An East Asia model. New York: Palgrave MacMillan.

Sparks, D.L. and S.T. Barnett, 2010. The informal sector in Sub-Saharan Africa: Out of the shadows to foster sustainable employment and equity? International Business \& Economics Research Journal, 9(5): 1-12.Available at: https://doi.org/10.19030/iber.v9i5.563.

UNIDO, 2010. Cluster development for pro-poor growth: The UNIDO approach. The UNIDO Programme. Business, Investment and Technology Services Branch, Programme Development and Technical Cooperation Division, Vienna.

Uzor, O., 2004. Small and medium scale enterprises cluster development in South-Eastern region of Nigeria. Institute for World Economics and International Management, University of Bremen, Germany. Available from http://www.iwim.uni-bremen.de [Accessed October 6, 2014].

Waits, M.J., 2000. The added value of the industry cluster approach to economic analysis, strategy development, and service delivery. Economic Development Quarterly, 14(1): 35-50.Available at: https://doi.org/10.1177/089124240001400106.

Weijland, H., 1999. Microenterprise clusters in rural Indonesia: Industrial seedbed and policy target. World Development, 27(9): 15151530.Available at: https://doi.org/10.1016/s0305-750x(99)00076-5.

Yamane, T., 1967. Statistics, an introductory analysis. 2nd Edn., New York: Harper and Row.

Zeibote, Z., 2018. The impact of clusters on regional competitiveness. Regional Formation and Development Studies, 25(2): 117131.Available at: https://doi.org/10.15181/rfds.v25i2.1750.

Appendix-1. Descriptive statistics of firms in cluster and non-clustered firms.

\begin{tabular}{|c|c|c|c|c|}
\hline Variables & Firm size & Cluster-mean & Non cluster -mean & Absolute t-value \\
\hline \multirow[t]{4}{*}{ Sales } & Small firms & 125,112 & $121,084.2$ & 0.3360 \\
\hline & Medium firms & 319,877 & $316,577.1$ & $1.9809^{* *}$ \\
\hline & Large firms & $4,444,094$ & $4,422,870$ & $2.0949^{* * *}$ \\
\hline & overall & $812,610.5$ & $613,153.8$ & 1.3615 \\
\hline \multirow[t]{4}{*}{ Capital } & Small firms & $110,265.3$ & $118,241.6$ & 0.4194 \\
\hline & Medium firms & $280,981.9$ & $279,997.4$ & 0.0161 \\
\hline & Large firms & $581,060.5$ & $901,700.8$ & 1.2432 \\
\hline & overall & $261,569.1$ & $303,664.9$ & 0.6848 \\
\hline \multirow[t]{4}{*}{ Labour } & Small firms & 2.89 & 2.62 & 0.6282 \\
\hline & Medium firms & 18.14894 & 17.0339 & $1.9057^{*}$ \\
\hline & Large firms & 36.60714 & 31.95 & 0.7196 \\
\hline & overall & 18.61458 & 18.44792 & 0.9121 \\
\hline \multirow[t]{4}{*}{ Profit } & Small firms & $25,789.54$ & $25,438.79$ & 1.0912 \\
\hline & Medium firms & $159,104.4$ & $142,901.9$ & $2.1503^{* *}$ \\
\hline & Large firms & 390,383 & $375,498.6$ & $2.2640^{* *}$ \\
\hline & overall & $139,907.8$ & $124,886.1$ & $2.1669^{* *}$ \\
\hline
\end{tabular}


Appendix-2. Regression results of the three models.

\begin{tabular}{|c|c|c|c|c|c|c|}
\hline \multirow[t]{2}{*}{ Variables } & \multicolumn{2}{|c|}{ Model 1} & \multicolumn{2}{|c|}{ Model 2} & \multicolumn{2}{|c|}{ Model 3} \\
\hline & Sales & Profit & Sales & Profit & Sales & Profit \\
\hline $\begin{array}{l}\text { Cluster } \\
\text { dummy }\end{array}$ & $\begin{array}{c}63799.3 \\
(1.47) \\
\end{array}$ & $\begin{array}{c}33351.4^{* * * * *} \\
(2.78)\end{array}$ & $\begin{array}{c}27069.4 \\
(1.33)\end{array}$ & $\begin{array}{c}33440.3^{* * *} * \\
(2.77)\end{array}$ & $\begin{array}{c}27480.9 \\
(1.36) \\
\end{array}$ & $\begin{array}{c}31050^{* * * *} \\
(2.72) \\
\end{array}$ \\
\hline Capital & $\begin{array}{c}1.700647 \text { **** } \\
(3.14)\end{array}$ & $\begin{array}{c}23.51677 \text { **** } \\
(2.66)\end{array}$ & $\begin{array}{c}1.611556 \text { **** } \\
(3.97)\end{array}$ & $\begin{array}{c}23.52155^{* * * *} \\
(2.66)\end{array}$ & $\begin{array}{c}1.606348 * * * * \\
(3.97)\end{array}$ & $\begin{array}{c}23.76177^{* * * *} \\
(2.71)\end{array}$ \\
\hline Labour & $\begin{array}{c}-4548.209 \\
(-1.11) \\
\end{array}$ & $\begin{array}{c}15263^{*} * * * \\
(2.93) \\
\end{array}$ & $\begin{array}{c}-4548.209 \\
(-1.14) \\
\end{array}$ & $\begin{array}{c}15470.4^{* * * * *} \\
(2.97) \\
\end{array}$ & $\begin{array}{c}31097.43^{* *} \\
(2.25) \\
\end{array}$ & $\begin{array}{c}16884.7^{* * * *} \\
(2.95)\end{array}$ \\
\hline $\begin{array}{l}\text { Experience of } \\
\text { firm head }\end{array}$ & $\begin{array}{c}42641.91 \text { *** } \\
(2.03)\end{array}$ & $\begin{array}{c}40576^{*} \\
(1.89)\end{array}$ & $\begin{array}{c}\text { 39993.58)*** } \\
(2.01)\end{array}$ & $\begin{array}{c}43059.28 \text { *** } \\
(1.99)\end{array}$ & & \\
\hline $\begin{array}{c}\text { Years of } \\
\text { education } \\
\text { of firm head }\end{array}$ & $\begin{array}{c}20259.1 \\
(1.58)\end{array}$ & $\begin{array}{c}46734.7 \\
(0.71)\end{array}$ & & & & \\
\hline $\begin{array}{c}\text { Age of firm } \\
\text { head }\end{array}$ & $\begin{array}{c}17549.8 \\
(1.02) \\
\end{array}$ & $\begin{array}{c}2769.428 \\
(0.10) \\
\end{array}$ & & & & \\
\hline $\begin{array}{c}\text { Access to } \\
\text { credit dummy }\end{array}$ & $\begin{array}{c}50,492.6 \text { *** } \\
(2.10)\end{array}$ & $\begin{array}{c}17,4196 \\
(0.85)\end{array}$ & $\begin{array}{c}40576 \\
(2.09) * *\end{array}$ & $\begin{array}{l}31850 \\
(1.27)\end{array}$ & & \\
\hline Constant & $\begin{array}{l}15563 \\
(1.34) \\
\end{array}$ & $\begin{array}{l}86423 \\
(1.19)\end{array}$ & $\begin{array}{l}18982 \\
(1.55)\end{array}$ & $\begin{array}{c}-74319.9 \\
(-0.55)\end{array}$ & $\begin{array}{c}50492.6 \\
(2.10)\end{array}$ & $\begin{array}{c}-10979.9 \\
(0.98)\end{array}$ \\
\hline R square & 0.3924 & 0.6165 & 0.4399 & 0.6154 & 0.4957 & 0.6085 \\
\hline $\mathrm{F}$ probability & 0.0046 & 0.0000 & 0.0029 & 0.0000 & 0.0004 & 0.0000 \\
\hline Mean VIF & 1.25 & 1.25 & 1.06 & 1.06 & 1.03 & 1.03 \\
\hline
\end{tabular}

